Ayurlog: National Journal of Research in Ayurved Science

http://www.ayurlog.com Volume: $6^{\text {th }} \mid$ Issue: $5^{\text {th }} \mid$ August 2018

\title{
A literary Review of Nidanapanchaka of Chhardi Vyadhi
}

\author{
Sarita Manikrao Kawale* 1 , Mhaske Rajesh ${ }^{2}$
}

1. M. D. (Scholar),

2. Associate Professor,

Department of Ronidan \& Vikruti vigyan,

P.D.E.A's College of Ayurved \& Research Centre, Nigdi, Pune- 44

*Corresponding author: Email: sarita.kawale@gmail.com; Mob. No. 9021639577

\section{ABSTRACT:}

Acharya Shushruta has explained chhardi is the impurities come out of mouth with forceful impulses covering the face and producing tearing pain in body. When udanavayu join with vyanvayu, impelling doshas aggravated by the use of incompatible food forces upwards. Due t its similarity it can be co-related wit modern disease emesis, vomiting. Sometime vomiting is considered as a disease and sometimes it is associate complaints with the other disease. Chhardi is explained by almost all samhita and granthas.

This article is based on Nidanapanchaka of Chhardi Roga from Ayurvedic texts as Madhavnidan, Charak samhita, Sushruta samhita, Astanga hrudaya etc with all commentaries. Annavaha srotas is chiefly involved in pathogenesis of Chhardi Roga. The changing lifestyle of human being by means of Ahara, Vihar and Manasik hetu plays a major role in manifestation of various diseases. Chhardi Roga is also one of them. The detail knowledge of Nidanapanchaka and types of Chhardi Roga will help in its diagnosis and management in this modern era also. So there is need to review of the nidanapanchaka of Chardivyadhi according to Ayurveda as well as modern science.

Keywords: Chhardi, Nidanapanchaka, Types, Vomiting, Emesis.

\section{Tntroduction:}

Acharya Charaka has explained in chhardi that the patient has intended to induce vomiting to expel out vitiated kapha \& pitta. Chhardi is Gastro-Intestinal disorder characterized by bouts of vomiting, nausea, pain and black outs. ${ }^{1}$ Chhardi is patho-physiological condition where the sufferer is exposed to particular predisposing factors for vomiting and as a result he suffers from the particular sign.

$$
\text { A detailed review of }
$$

Nidanapanchaka (i.e. Nidana, Purvarupa, Rupa, Upashaya and Samprapti) will be helpful for clear understanding of minute aspects connected to disease. This aids in diagnosis and treatment of a disease with high precession. Therefore in this article Nidanapanchaka of Chhardi Roga has been reviewed from authoritative 
Ayurveda Samhitas and textbooks with rational approach to elucidate different attributes connected to Chhardi Roga.

\section{Material and Methods:}

This article is based on review of Nidanpanchaka of Chhardi Roga from available Ayurvedic texts and Samhitas. Principal texts referred are Charak Samhita, Susruta samhita, Astanga hrudaya, Astang sangraha and Madhava nidana along with commentaries.

\section{Nidanapanchaka of Chhardi Roga: \\ - Hetu (Etiological Factors):}

According to Ayurveda hetus of chhardi vyadhi are mentioned in various granthas, samhitas.

1) Madhavnidana: Atidrava (excessive liquids), Ati-snigdha (unctous), Ahruddya, Ajeerna, Lavanaraspradhan (excessive. salty food), Shram, Bhaya (fear), Krim Akale-atimatrasyaahar, Asatmyaaahar, Vibhatsa-darshan, Douhrudini avasthagarbhini avastha ${ }^{2}$.

\section{2) Charka Samhita:}

- Vataja: Vyayam, excessive intake of medicines having tiksna (sharp) attributes, Shoka, Bhaya, Roga (disease), Upvasa (fasting).

- Pittaja:(Ajina katu-Amla aahar) As a result of intake of food before the previous meal is digested or taking pungent, sour, vidahi (causing burning sensation) and cold diet.

- Kaphaja: Atisnigdha sevana (As a result of the intake of unctuous), Guru gunadi (excessively heavy), ama (raw/uncooked) and vidahi (causing burning sensation) food and because of excessive sleep and similar other factor.
- Sannipataja: Due to eating sorts of things constantly, excessive defect of ama and rutu viparit (seasonal perversions), all the dosha get vitiated simultaneously and thus cause vomiting caused by tridosha.

- Dwishtarthasamyogaja: When a person vomits, as a result of mental disgust occasioned by sense contact with despicable, antagonistic unclean, putried, unholy and loathsome odour, diet or sights ${ }^{3}$.

3) Sushrut Samhita: One who consumes foods which are Atidrava-excessive liquids, Atisnigdha-fatty substances, Ahrudra-atilavana (disgusting items and salty articles), taking food unsuitable, at improper time and in excessive quantity, exertion, fasting, agitation, indigestion, helminthic infestation, Garbhadoshaduring pregnancy in women, eating hurriedly and presence of excessive $a m a{ }^{4}$

The causative factors described in modern science are responsible for chhardi (Vomiting) are as toxic, reflex, central or obstructive. Vomiting is a complex reflex synchronous contraction of a diaphragm, inter costal muscles and abdominal muscles raises intra-abdominal pressure and combined with relaxation of the lower oesophageal sphincter, results in forcible ejection of gastric contents.

Etiology of emesis (vomiting) is described in below...

1) Gastro-intestinal causes: Gastritis, Peptic ulcer disease, Pyloric stenosis, Intestinal obstruction, Gastro paresis, Pancreatitis, Gastric cancer, Liver cirrhosis, Appendicitis, Cholecystitis. 
2) Toxins: Food poisoning, Uraemia, Alcoholism

3) CNS causes: Migrane, Meningitis, Raised intra-cranial pressure, vestibular neuronitis.

4) Infections: Hepatitis, Gastroenteritis, Urinary tract infection

5) Metabolic disorders: Diabetic ketoacidosis, Addison's disease, cyclical vomiting syndrome, hyperparathyroidism.

6) Drugs: NSAIDs, Opiates, Digoxin, Antibiotics, Cytotoxic. ${ }^{5}$

\section{- Bheda (Types):}

In chhardi five types are mentioned Vataj, Pittaj, Kaphaj, Sannipatika and Aagantuja. In Aagantuja chhardi caused by vibhastadarshan, douhrudini, amadosa, sudden change from suitable desha and krimi. $^{6}$

\section{- Samprapti:}

Nidanas will lead to vitiation of Kaphadosha and Pitta dosha which in turn vitiate Vata which forces the Doshas to move in upward direction leading to Chhardi. The Kaphadushti together with the Pitta dushti will lead Utklishtata of Dosha or Aamasanchaya. These Utklishta doshas can cause Avarodha to the Gati of vata which in turn brings about Kshobha to Amashaya. The Utklishta doshas are expelled out through the mouth by the action of Udana and Vyanavata resulting in Chhardi. ${ }^{7}$

\section{Samprapti Ghataka:}

- Dosa -Vata Pradhana Tridosa (mainly Udana, Samana and Vyan vata)

Kapha- Kledaka, Pitta- Pachaka

- Dusya-Rasadhatu, Puriushmala
- Agni - Jatharagni, Dhatwagni

- Srotas-Annavaha

- Srotodushti - Vimargagamana and Sanga

- Udbhavasthana - Amashaya, Hridaya

- Sanchara-Kostha

- Adhisthana-Amashaya

- Udbhavasthana: Amashaya, Kostha

- Roga Marga-Abhuyuanutara

- Purvarupa:

Premonitory signs and symptoms of Chhardi Roga are as follows...

Hrullasa, Kaphapraseka, Dweshaashana ${ }^{8}$, Uddgararodha ${ }^{9}$,

Lavanapraseka ${ }^{10}$

\section{- Rupa :}

Lakshana of Chhardi Vyadhi are as bllows...

Vataja- Hruparshpida, Mukhashosha, shirshool, Nabhishool, Kas, Swarbheda, Toda, udgarshabdaprabala chhardi (vomiting with great sound of eructation), Saphen-vichhinnakrunna tanu chhardi and Kashaya rasatmaka chhardi. Vomits with severe impulse with difficulty only small amount associated with great distress and vomiting is more after digestion of food. ${ }^{11}$

2) Pittaja: Murchha (Fainting), Pipasa, Mukhashosha, Murdhatalvakshisantapa (Burning sensation of head, palates, eyes), Tama, Bhrama, PittaBrushoshna-harita Chardi, ${ }^{12}$ katu-tikta rasatmaka chhardi, Sadaha chhardi, Jwar, ${ }^{13}$ Amla-katu rasatmaka, ushnagunatmaka chhardi ${ }^{14}$ 
3) Kaphaja: Tandra, Madhura Kaphapraseka, Santosha, Nidra, Aruchi, Gaurav, Snigdha-GhanaSwada-Shudhha Chardi, Saromahasha-alparuja. ${ }^{15}$ Abhakta, Madhuprabhut-shukla-Heem Sandrakapha mishrit chhardi. ${ }^{16}$

4) Sannipataka: Udarshool, Vipak, Aruchi, Daha, trushna, Shwas, Pramoha, Lavana-Amla-Neel-SandraUshna-Raktatmaka Chhardi ${ }^{17}$

5) Krimija: Udarshool, Hrullas and other symptoms of krimija hrudroga are observed. ${ }^{18}$

- Upadrava (complications):

Excessively exacerbated Vata obstruct the channels carrying Purish, Sweda, Mutra and Ambu moves upwards and expels accumulated doshas out of gastro-intestinal tract in the person having excited doshas. Then the patients vomit material with colour and odour of urin and stool and associated with Trushna (Thirst), Shwas (Dyspnoea), Hikka (hiccup), Jwara, Hrudroga, Tamakashwas, foetid and bouts of chhardi with great force. $^{19}$

\section{- Sadhyasadhyata (Prognosis of Chhardi):}

Excessive vomiting in emaciated person, which is too severely complicated and associated with blood and pus, moon like luster is indicative of the incurable nature of disease. Vomiting which is free from complications i.e. curable. ${ }^{20}$

\section{Conclusion:}

Chhardi vyadhi was in acute stage i.e. curable or manageable but in chronic stage they are incurable. Most of the time vomiting found in associated complaints of other disease. The study of Nidanapanchaka will helpful in accurate understanding of Nidana, Purvarupa, Rupa, aggravating factors, relieving factors and prognosis of Chhardi Roga and it is helpful in prevent the disease as a Nidanparivarjana.

\section{References:}

1. Priyavrat Sharma, Charaksamhita volume $2^{\text {nd, }}$ Varanasi: Chaukhambha Orientalia, $6^{\text {th }}$ edition 2001, Pg. No.335

2. Brahmanand Tripathi, Madhavnidanam, Volume $1^{\text {st }}$, Varanasi: Chaukhambha Surabharati Prakashan, Reprint 2003, Pg. no.409

3. Priyavrat Sharma, Charaksamhita volume $2^{\text {nd, }}$ Varanasi: Chaukhambha Orientalia, $6^{\text {th }}$ edition 2001, Pg. No.335

4. Kaviraj Kunjalal Bhishagra, Dr. Laxmidhar Dwivedi, Sushrutasamhita Volume $3^{\text {rd }}$, Varanasi: Choukhambha Sanskrit Series Office, $2^{\text {nd }}$ edition 2002, Adhyay 49-

Chhardipratishedha, Pg. no. 501

5. K.R. Palmer \& I.D. Penman, 22Alimentary tract and pancreatic disease, Nicki R. Colledge, Brian R. Walker and Stuart H. Ralston, Davidson's Principle and practice of Medicine, Churchill Livingstone Elsevier, $21^{\text {st }}$ edition 2010, Pg. no. 852

6. Priyavrat Sharma, Charaksamhita volume $2^{\text {nd, }}$ Varanasi: Chaukhambha Orientalia, $6^{\text {th }}$ edition 2001, Pg. No.335

7. Priyavrat Sharma, Charaksamhita volume $2^{\text {nd, }}$ Varanasi: Chaukhambha Orientalia, $6^{\text {th }}$ edition 2001, Pg. No.335 
8. Priyavrat Sharma, Charaksamhita volume $2^{\text {nd, }}$ Varanasi: Chaukhambha Orientalia, $6^{\text {th }}$ edition 2001, Pg. No.335

9. Kaviraj Kunjalal Bhishagra, Dr. Laxmidhar Dwivedi, Sushrutasamhita Volume $3^{\text {rd }}$, Varanasi: Choukhambha Sanskrit Series Office, $2^{\text {nd }}$ edition 2002, Pg. no. 502

10. K. R. Shrikantha Murthy, Astanga hrudaya of Vagbhata Volume $1^{\text {st }}$, Varanasi: Chaukhambha Orientalia, $5^{\text {th }}$ edition 2003, Pg. no. 50

11. Priyavrat Sharma, Charaksamhita volume $2^{\text {nd, }}$ Varanasi: Chaukhambha Orientalia, $6^{\text {th }}$ edition 2001, Pg. No.335

12. Priyavrat Sharma, Charaksamhita volume $2^{\text {nd, }}$ Varanasi: Chaukhambha Orientalia, $6^{\text {th }}$ edition 2001, Pg. No.335

13. Kaviraj Kunjalal Bhishagra, Laxmidhar Dwivedi, Sushrutasamhit Volume $3^{\text {rd }}$, Varanasi: Choukhambha Sanskrit Series Office, $2^{\text {nd }}$ edition 2002, Pg. no. 502-503

14. K. R. Shrikantha Murthy, Astanga hrudaya of Vagbhata Volume $1^{\text {st }}$,
Varanasi: Chaukhambha Orientalia, $5^{\text {th }}$ edition 2003, Pg. no. 50-51

15. Priyavrat Sharma, Charaksamhita volume $2^{\text {nd, }}$ Varanasi: Chaukhambha Orientalia, $6^{\text {th }}$ edition 2001, Pg. No.335

16. K. R. Shrikantha Murthy, Astanga hrudaya of Vagbhata Volume $1^{\text {st }}$, Varanasi: Chaukhambha Orientalia, $5^{\text {th }}$ edition 2003, Pg. no. 50-51

17. Priyavrat Sharma, Charaksamhita volume $2^{\text {nd, }}$ Varanasi: Chaukhambha Orientalia, $6^{\text {th }}$ edition 2001, Pg. No.336

18. Priyavrat Sharma, Charaksamhita volume $2^{\text {nd, }}$ Varanasi: Chaukhambha Orientalia, $6^{\text {th }}$ edition 2001, Pg. No.336

19. Brahmanand Tripathi, Madhavnidanam, Volume $1^{\text {st }}$, Varanasi: Chaukhambha Surabharati Prakashan, Reprint 2003, Pg. no.417

20. Priyavrat Sharma, Charaksamhita volume $2^{\text {nd, }}$ Varanasi: Chaukhambha Orientalia, $6^{\text {th }}$ edition 2001, Pg. No.337

\section{Cite article:}

A literary Review of Nidanapanchaka of Chhardi Vyadhi Sarita Manikrao Kawale, Mhaske Rajesh

Ayurlog: National Journal of Research in Ayurved Science- 2018; (6)(5) : 1-5 